\title{
OBSERVATIONS ON THE TRAVEL OF SHORE MATERIAL ALONG A CHALK FORESHORE
}

\author{
H. W. Coultas \\ University of Birmingham \\ England
}

\begin{abstract}
(Editor's note - The date presented in this paper were published under the above titie in 1920 in the journal of the Institution of Munioipel and County Engineers (now the Institution of Munloipal Engineers). Beoause this paper presents the only known measurements on the littorel movement of relatively ooarse material by wave action, an abstract is presented below to aoquaint ongineers with this souroe of information.)
\end{abstract}

\section{ABSTRACT}

The paper deals with the results of a few experiments on the travel of shingle oarriod out at Rottingdean, noar Brighton, by the Author, wh1lst he was in oharge of the sea defenoe works, whioh were beling oreoted for the East Sussex County Couno1l. The defence works consist of a number of oonorete groynes oonneoted together at the oliff ends by reinforoed concrete sea walls. The groynes are 600 feet apart, and it was between two of these that the experiments were oarried out. The foreshore 18 of chall, and the amount of shingle between the groynes was very small. Often this shingle was heaped up in one of the oornors made by the sea wall and the groyne; the remainder of the shore was absolutely bare. This ma an adrantage, as the speoimens oould be plooed on the olear portion of the shore, and their movements observed, with a minimum danger of their being lost and unrecognised by being in a largo mass of shingle. In order to reoognise the test pleoes, speoimens of briok, oonorete and granite were used to distinguish them from the shingle flints. But in spite of this and a long olear run of shore, there was sufficient shingle between the groynes to hide the test speoimens onoe, they had got into the main heap after a rough sea.

The coast line at Rottingdean runs practically west to east, and the groynes are approximately at right angles to the coast line. The prevailing wind is south-westerly, and the direction of the tidal flood current is west to east. Very bad south-easterly gales occur, but the probability of these is one to about four south-west gales. The tests show that the prevailing travel of the heavy shore material is in the direction of the prevailing wind, and the tidal flood current. Another difficulty in carrying out tests between groynes is, that if a specimen is placed in a corner of a groyne and a sea wall the specimen simply moves about in this corner for a considerable period of time, and only a heavy gale will get it out of this position. Consequently, such a specimen cannot be used for ascertaining the travel of shingle along the shore. It is, however, of interest in showing the action of a groyne in trapping shinglo. It will be shown later that shingle specimens placed 
near a groyne at some distance from the cliff travelled up the groyne and collected in the corner of the sea wall and the groyne. If, therefore, there is a large amount of shingle moving along a coast line, and a quantity of it meets a groyne at some distance from the shore, the groyne will cause the trapped shingle to move toward the shore, where it will collect in such a corner as has been mentioned. If a large amount is trapped, there will be a fairly rapid growth of the amount of shingle in this position. Given that the groynes are not too far apart, rough seas will tend to distribute some of the material between them, and in time a shingle bank will be formed, and thus a buttress made on the shore to resist wave action and to minimise erosion.

If the flow of shingle along a length of ooast line is stopped, or partially stopped, then in a very short period of time the natural wave buffer will disappear, and the actual coast line exposed to wave action, when erosion will take place. It is, therefore, essential that when groynes and other similar obstruotions are being built, they should be so oonstructed that the natural flow of material along a ooast line is not stopped altogether, and that complete natural flow is restored in as short a time as possible. 